\title{
STUDI KELAYAKAN USAHA WARALABA WARUNG "PANGESTU" DI KABUPATEN JEMBER
}

\author{
Oleh:
}

DESSY PUTRI ANDINI *)

\begin{abstract}
ABSTRAK
Kondisi perekonomian yang sangat sulit saat ini menuntut sebuah unit bisnis untuk bisa menciptakan sebuah unit bisnis yang prospektif dan menguntungkan dalam jangka pendek dan jangka panjang sebagai tempat untuk melakukan investasi. Pemikiran yang kedua adalah dengan modal yang pas - pasan, produk yang diproduksi harus dapat diterima oleh pasar sehingga memunculkan permintaan pasar dan dapat memberikan keuntungan bagi bisnis kita. Oleh karena itu, kita perlu untuk melakukan studi kelayakan sebuah unit bisnis agar mampu bersaing di dunia bisnis.

Penelitian ini bertujuan untuk mengetahui kelayakan usaha waralaba "PANGESTU" dengan menggunakan metode Payback Period, metode Benefit Cost Ratio (BCR), metode Net Present Value (NPV) yaitu metode yang menghitung selisih nilai dengan penerimaan kas bersih dimasa yang akan datang dan metode Internal Rate of Return (IRR) yaitu untuk mencari tingkat bunga. Dari hasil perhitungan dengan menggunakan metode $P P$ diperoleh hasil, yaitu 2 tahun 2 bulan, lebih cepat dari umur ekonomis usaha selama 5 tahun. BCR memiliki nilai lebih dari 1 yang menunjukkan bahwa usaha ini layak untuk diusahakan. $N P V$ bernilai positif, yaitu Rp. 1.099.768.059. IRR bernilai $85,95 \%$ lebih besar dari tingkat bunga yang telah ditetapkan yaitu $15 \%$. Sehingga jika usaha ini diwaralabakan pasti banyak yang akan membeli usaha ini.
\end{abstract}

Kata Kunci : Kelayakan Usaha, PP, BCR, NPV, IRR.

\section{PENDAHULUAN}

\subsection{Latar Belakang}

Problematika mengenai angka pengangguran di Indonesia tentu bukan hal baru lagi bagi masyarakat kita. Bahkan menurut Badan Pusat Statistik (Maret 2011), saat ini terdapat lebih dari 8,13 juta jiwa atau setara dengan 6,8 persen pengangguran yang tersebar di seluruh wilayah Indonesia. Hal ini menjadi salah satu bukti nyata bahwa tingkat pengangguran di negara kita masih cukup tinggi, meskipun jumlah tersebut sudah mengalami penurunan dibandingkan tahun-tahun sebelumnya. Rendahnya daya serap tenaga kerja di Indonesia membuat kondisi tersebut belum bisa diselesaikan secara tuntas oleh pihak pemerintah maupun instansi terkait lainnya. Karena itulah dibutuhkan solusi tepat untuk mengurangi jumlah pengangguran yang setiap harinya menunjukan peningkatan. Salah satunya yaitu dengan mendorong laju pertumbuhan usaha kecil menengah di seluruh penjuru Indonesia.

Usaha Kecil dan Menengah (UKM) mempunyai peran yang strategis dalam pembangunan ekonomi nasional. Selain berperan dalam pertumbuhan ekonomi dan penyerapan tenaga kerja juga berperan dalam pendistribusian hasil-hasil pembangunan. Dalam krisis ekonomi yang terjadi di Indonesia beberapa waktu yang lalu, dimana banyak usaha berskala besar yang mengalami stagnasi bahkan berhenti aktifitasnya, sektor Usaha Kecil dan Menengah (UKM) terbukti lebih tangguh dalam menghadapi krisis tersebut.

Tumbuhnya UKM-UKM di Indonesia menjadi langkah awal bagi perbaikan ekonomi nasional hingga akhirnya target pemerintah untuk menurunkan angka kemiskinan menjadi $8 \%$ di tahun 2014 bisa segera terwujud dengan penciptaan lapangan kerja bagi seluruh lapisan masyarakat Indonesia.

Usaha Kecil dan Menengah (UKM) di bidang makanan sangat menjamur di berbagai kota terutama di kota Jember. Hampir semua orang tidak ada yang menolak keberadaan jenis produk ini. Apalagi Indonesia kaya dengan macam ragam makanan khas daerah. Hal ini dapat dilihat dengan semakin banyaknya usaha makanan yang bermunculan menawarkan beragam makanan unik dan kreatif. Mulai dari makanan rumahan hingga makanan restoran, pemasarannya juga beragam dari yang tradisional hingga modern yaitu melalui sistem waralaba (franchise). 
Menjalankan bisnis waralaba memiliki banyak keuntungan diantaranya menghemat tahapan bisnis seperti membangun image bisnis yan baik di mata konsumen dan penentuan branding. Selain itu pemilik merk franchise dapat menambah outlet tanpa biaya sedangkan pembeli franchise dapat membuka outlet dari sebuah unit bisnis yang sudah berjalan. Kecermatan dalam memilih lokasi dan target konsumen menjadi hal yang sangat penting bagi pembeli franchise. Hal tersebut merupakan faktor utama kesuksesan dalam mengelola usaha franchise.

Telah ada banyak orang yang berhasil dengan memilih franchise dengan modal kecil berupa produk makanan. Kombinasi branding produk yang baik, lokasi outlet yang strategis, kemasan produk yang menarik, pelayanan yang memuaskan serta produk yang berkualitas menjadi jaminan sukses menjalankan bisnis franchise makanan.

Oleh karena itu, sebelum kita memulai sebuah usaha diperlukan rencana usaha agar usaha kita nantinya dapat menguntungkan. Studi kelayakan usaha dibuat untuk mengetahui apakah rencana usaha layak atau tidak untuk dilaksanakan. Pendirian usaha waralaba "PANGESTU" merupakan suatu usaha yang sangat menguntungkan karena setiap hari manusia membutuhkan makan. Apalagi saat ini banyak ibuibu yang bekerja sehingga mereka tidak sempat memasak makanan untuk keluarganya. Jalan pintas untuk memenuhi kebutuhan makan keluarganya dengan cara membeli di warung atau rumah makan. Sehingga bisnis makanan saat ini sangat menguntungkan.

Untuk melihat kelayakan usaha waralaba warung "PANGESTU" maka dibuatlah penelitian dengan judul "Studi Kelayakan Usaha Waralaba "PANGESTU" di Kabupaten Jember."

\subsection{Rumusan Masalah}

Kondisi perekonomian yang sangat sulit saat ini menuntut sebuah unit usaha bisnis untuk bisa menciptakan sebuah unit usaha bisnis yang prospektif dan menguntungkan dalam jangka pendek dan jangka panjang sebagai tempat untuk melakukan investasi. Pemikiran yang kedua adalah dengan modal yang pas - pasan, produk apa yang akan kita produksi sehingga memunculkan permintaan pasar dan dapat memberikan keuntungan bagi bisnis kita tersebut. Oleh karena itu, kita perlu untuk melakukan studi kelayakan usaha sebuah unit bisnis agar mampu bersaing di dunia bisnis.

Hal yang mendasari permasalahan yang ada di penelitian ini yaitu apakah usaha waralaba warung "PANGESTU" layak untuk dijalankan dan berapa lama waktu yang diperlukan agar modal yang ditanamkan dalam investasi waralaba tersebut dapat diperoleh kembali seluruhnya?

\subsection{Tujuan}

Berkaitan dengan rumusan masalah maka tujuan yang ingin dicapai dalam penelitian ini adalah untuk mengetahui kelayakan usaha waralaba warung "PANGESTU" dan untuk mengetahui jangka waktu yang diperlukan agar modal yang ditanamkan dalam investasi waralaba tersebut dapat diperoleh kembali seluruhnya.

\subsection{Manfaat}

Penelitian ini diharapkan dapat bermanfaat sebagai:

1. Tambahan informasi dan bahan kajian untuk para usahawan baru dalam mengambil keputusan berinvestasi sehingga dapat meraup keuntungan dari unit bisnisnya terutama di bidang makanan.

2. Membantu mengevaluasi unit bisnis waralaba warung "PANGESTU" untuk meningkatkan keuntungannya.

3. Menambah khasanah penelitian di bidang manajemen terutama manajemen keuangan.

\section{TINJAUAN PUSTAKA}

\subsection{Landasan Teori \\ 2.1.1 Pengertian Waralaba}

Waralaba adalah hak-hak untuk menjual suatu produk atau jasa maupun layanan. Sedangkan menurut versi pemerintah Indonesia, yang dimaksud dengan waralaba adalah perikatan dimana salah satu pihak diberikan hak memanfaatkan dan atau menggunakan hak dari kekayaan intelektual (HAKI) atau pertemuan dari ciri khas usaha yang dimiliki pihak lain dengan suatu imbalan berdasarkan persyaratan yang ditetapkan oleh pihak lain tersebut dalam rangka penyediaan dan atau penjualan barang dan jasa (Ekotama : 2008).

Di Indonesia, sistem waralaba mulai dikenal pada tahun 1950-an, yaitu dengan munculnya dealer kendaraan bermotor melalui pembelian lisensi. Perkembangan kedua dimulai pada tahun 1970-an, yaitu dengan dimulainya sistem pembelian lisensi plus, yaitu franchisee tidak sekedar menjadi penyalur, namun juga memiliki hak untuk memproduksi produknya. Agar waralaba dapat berkembang dengan pesat, maka persyaratan utama yang harus dimiliki satu teritori adalah kepastian hukum yang mengikat baik bagi franchisor maupun franchisee. Karenanya, kita dapat melihat bahwa di negara yang memiliki kepastian hukum yang jelas, waralaba berkembang pesat, misalnya di AS dan Jepang. Tonggak kepastian hukum akan format waralaba di 
Indonesia dimulai pada tanggal 18 Juni 1997, yaitu dengan dikeluarkannya Peraturan Pemerintah (PP) RI No. 16 Tahun 1997 tentang Waralaba. PP No. 16 tahun 1997 tentang waralaba ini telah dicabut dan diganti dengan PP no 42 tahun 2007 tentang Waralaba. Selanjutnya ketentuan-ketentuan lain yang mendukung kepastian hukum dalam format bisnis waralaba adalah sebagai berikut :

- Keputusan Menteri Perindustrian dan Perdagangan RI No. 259/MPP/KEP/7/1997 Tanggal 30 Juli 1997 tentang Ketentuan Tata Cara Pelaksanaan Pendaftaran Usaha Waralaba.

- Peraturan Menteri Perindustrian dan Perdagangan RI No. 31/M-DAG/PER/8/2008 tentang Penyelenggaraan Waralaba

- Undang-undang No. 14 Tahun 2001 tentang Paten.

- Undang-undang No. 15 Tahun 2001 tentang Merek.

- Undang-undang No. 30 Tahun 2000 tentang Rahasia Dagang.

Banyak orang masih skeptis dengan kepastian hukum terutama dalam bidang waralaba di Indonesia. Namun saat ini kepastian hukum untuk berusaha dengan format bisnis waralaba jauh lebih baik dari sebelum tahun 1997. Hal ini terlihat dari semakin banyaknya payung hukum yang dapat melindungi bisnis waralaba tersebut. Perkembangan waralaba di Indonesia, khususnya di bidang rumah makan siap saji sangat pesat. Hal ini ini dimungkinkan karena para pengusaha kita yang berkedudukan sebagai penerima waralaba (franchisee) diwajibkan mengembangkan bisnisnya melalui master franchise yang diterimanya dengan cara mencari atau menunjuk penerima waralaba lanjutan. Dengan mempergunakan sistem piramida atau sistem sel, suatu jaringan format bisnis waralaba akan terus berekspansi. Ada beberapa asosiasi waralaba di Indonesia antara lain APWINDO (Asosiasi Pengusaha Waralaba Indonesia), WALI (Waralaba \& License Indonesia), AFI (Asosiasi Franchise Indonesia). Ada beberapa konsultan waralaba di Indonesia antara lain IFBM, The Bridge, Hans Consulting, FT Consulting, Ben WarG Consulting, JSI dan lain-lain. Ada beberapa pameran Waralaba di Indonesia yang secara berkala mengadakan roadshow diberbagai daerah dan jangkauannya nasional antara lain International Franchise and Business Concept Expo (Dyandra),Franchise License Expo Indonesia (Panorama convex), Info Franchise Expo (Neo dan Majalah Franchise Indonesia).

\subsubsection{Pengertian Investasi}

Secara umum, investasi adalah penanaman modal (baik modal tetap maupun modal tidak tetap) yang digunakan dalam proses produksi untuk memperoleh keuntungan suatu perusahaan. Menurut Halim (2005), investasi pada hakikatnya merupakan penempatan sejumlah dana pada saat ini dengan harapan untuk memperoleh keuntungan di masa mendatang.

\subsubsection{Pengertian Aliran Kas (Cash Flow)}

Setiap usulan pengeluaran modal selalu mengandung dua macam aliran kas yaitu aliran kas keluar netto (net outflow of cash) yaitu yang diperlukan untuk investasi baru dan aliran kas masuk netto tahunan (net annual inflow of cash) yaitu sebagai hasil dari investasi baru tersebut, sering pula disebut "net cash procceds" atau "procceds".

\subsubsection{Pengertian Studi Kelayakan Bisnis}

Ada beberapa definisi dari pengertian Studi Kelayakan Bisnis menurut beberapa ahli. Berikut ini definisi dari pengertian studi kelayakan bisnis, yaitu kegiatan untuk menilai sejauh mana manfaat yang dapat diperoleh dalam melaksanakan suatu kegiatan usaha atau proyek.

Maksud dari sejauh mana manfaat yang dapat diperoleh disini adalah pada akhir-akhir ini telah banyak dikenal oleh masyarakat, terutama masyarakat yang bergerak dalam bidang dunia usaha. Bermacam-macam peluang dan kesempatan yang ada dalam kegiatan dunia usaha, telah menuntut perlu adanya penilaian sejauh mana kegiatan atau kesempatan tersebut dapat memberikan manfaat bila diusahakan.

Dengan demikian studi kelayakan yang juga sering disebut dengan feasibility study merupakan bahan pertimbangan dalam mengambil suatu keputusan, apakah menerima atau menolak dari suatu gagasan usaha atau proyek yang direncanakan.

Pengertian layak dalam penilaian ini adalah kemungkinan dari gagasan usaha atau proyek yang akan dilaksanakan memberikan manfaat, baik dalam arti manfaat finansial maupun dalam arti manfaat sosial. Layaknya suatu gagasan usaha atau proyek dalam arti manfaat sosial tidak selalu menggambarkan layak dalam arti manfaat finansial, hal ini tergantung dari segi penilaian yang dilakukan (Ibrahim, 2003).

\subsubsection{Fungsi Studi Kelayakan Bisnis}

Dilihat dari segi perbankan dan lembaga keuangan lainnya, peranan studi kelayakan bisnis menjadi lebih penting lagi untuk mengadakan penilaian terhadap gagasan usaha atau proyek yang mempunyai sumber dana dari lembaga tersebut.

Dengan adanya studi kelayakan dalam berbagai kegiatan usaha atau proyek dapat diketahui sampai seberapa jauh gagasan usaha yang dilaksakan mampu menutupi segala 
kewajiban-kewajiban serta prospeknya di masa yang akan datang. Berdasarkan pada hasil penilaian ini pula, para pihak perbankan akan menyetujui atau tidak terhadap permintaan kredit dari usaha atau proyek yang diusulkan. Perlu juga diketahui, penentuan kredit bukan hanya tergantung pada studi kelayakan yang diajukan, tapi juga tergantung pada jaminan kredit, koneksi, atau hubungan antara pihak pengusaha dengan pihak perbankan disamping bonafide tidaknya pengusaha tersebut namun demikian peranan studi kelayakan mempunyai andil yang cukup besar dalam mendapatkan kredit.

Bagi penanam modal, studi kelayakan merupakan gambaran tentang usaha atau proyek yang akan dikerjakan dan melalui studi kelayakan mereka akan dapat mengetahui prospek perusahaan dan kemungkinan-kemungkinan keuntungan yang diterima. Dengan studi kelayakan mereka akan dapat mengetahui jaminan keselamatan dari modal yang ditanam dan berdasarkan studi kelayakan ini pula mereka akan mengambil keputusan terhadap investasi.

Berdasarkan pada uraian ini, peranan studi kelayakan dan analisis proyek dalam kegiatan pembangunan cukup besar dalam mengadakan penilaian terhadap kegiatan usaha atau proyek yang akan dilaksanakan. Demikian pula terhadap para pengusaha ekonomi lemah, pada umumnya masalah yang dihadapi para pengusaha, selain keterbatasan modal, juga keterbatasan sumber daya dalam melihat prospek usaha atau proyek yang dikembangkan. Hal ini merupakan masalah baru yang memerlukan pemecahan secara terpadu untuk pengembangan usaha. Bertitik tolak pada permasalahan di atas, untuk meningkatkan peranan para pengusaha ekonomi lemah dalam perekonomian nasional, selain mengatasi masalah permodalan juga diperlukan peningkatan sumber daya melalui penataran, terutama dalam hal studi kelayakan bisnis (Ibrahim, 2003).

\subsubsection{Tujuan Studi Kelayakan Bisnis}

Tujuan dilakukan studi kelayakan adalah untuk menghindari keterlanjuran penanaman modal yang terlalu besar untuk kegiatan yang ternyata tidak menguntungkan, untuk menghindari resiko kegagalan suatu proyek yang menyangkut investasi dalam jumlah besar (Husnan dan Suwarsono, 2000).

\subsubsection{Metode Analisis Kelayakan Usaha}

Analisis kelayakan adalah penelitian yang mendalam terhadap suatu ide bisnis tentang layak atau tidaknya ide tersebut untuk dilaksanakan. Analisis kelayakan juga dapat diartikan sebagai suatu kegiatan yang mempelajari secara mendalam tentang suatu usaha atau bisnis yang akan dijalankan, dalam rangka menentukan layak atau tidaknya usaha tersebut dijalankan. Ada beberapa metode yang dapat digunakan untuk menganalisis kelayakan investasi diantaranya :

a. Metode Payback Period (PP) adalah suatu metode yang menggambarkan panjangnya waktu yang diperlukan agar dana yang dikeluarkan/tertanam dalam suatu investasi dapat diperoleh kembali seluruhnya. Metode ini diperlukan untuk dapat menutup kembali pengeluaran investasi dengan menggunakan aliran kas netto. Dalam perhitungan harus diketahui berapa besar dana yang dikeluarkan (Biaya Tetap + Biaya Operasional), kemudian berapa besar pendapatan yang diperoleh dalam masa.periode pemeliahraan di tambak.

Kriteria kelayakannyaa adalah :

1. Investasi dikatakan layak jika masa pemulihan modal investasi lebih pendek dari usia ekonomis.

2. Investasi dikatakan tidak layak jika masa pemulihan modal investasi lebih lama dibandingkan usia ekonomisnya.

b. Metode Benefit Cost Ratio (BCR) adalah perbandingan antara total pendapatan selama masa tertentu (besarnya manfaat) dengan capital out lay. Besarnya nilai BCR akan menunjukkan tingkat keuntungan yang dicapai. Apabila BC ratio lebih dari 1,0 (satu), maka usaha yang dijalankan adalah layak untuk diusahakan/dapat diteruskan.

c. Metode (Net Present Value) NPV, Merupakan metode analisis keuangan yang memperhatikan adanya perubahan nilai uang karena faktor waktu; proyeksi arus kas dapat dinilai sekarang (periode awal investasi) melalui pemotongan nilai dengan faktor pengurang yang dikaitkan dengan biaya modal (persentase bunga).

Kriteria kelayakannya adalah :

1. Perusahaan dinilai layak jika NPV bernilai positif, dan

2. Dinilai tidak layak dari aspek keuangan jika NPV bernilai negatif.

d. Metode (Internal Rate of Return) IRR adalah tingkat bunga yang akan diterima $(P V$ Future Procceds) sama dengan jumlah nilai sekarang dari pengeluaran modal ( $P V$ Capital Outlays).

Kriteria kelayakannya adalah :

1. Investasi dikatakan layak jika IRR lebih besar dari persentase biaya modal (bunga kredit) atau sesuai dengan persentase keuntungan yang ditetapkan investor, sebaliknya;

2. Dinilai tidak layak jika IRR lebih kecil dari biaya modal (bunga kredit) atau lebih rendah dari keinginan investor. 


\subsection{Penelitian Terdahulu}

Penelitian tentang analisis usaha telah banyak dilakukan di berbagai unit usaha baik di sektor pertanian, perikanan ataupun sektor makanan dan minuman. Penelitian terdahulu yang telah dilakukan oleh Budi Raharjo (2009) untuk melihat kelayakan usaha dan strategi pengembangan industri meubel di Kecamatan Suruh Kabupaten Semarang dengan populasi dalam penelitian tersebut adalah unit-unit usaha industri kecil meubel di Kecamatan Suruh Kabupaten Semarang yang berjumlah 30 unit usaha. Berdasarkan hasil perhitungan analisis kelayakan usaha didapatkan hasil Net Present Value (NPV) sebesar Rp. 452.950.625,43, nilai Benefit Cost Ratio (BCR) sebesar 1,55 dan nilai Internal Rate of Return (IRR) sebesar 18,7\%. Yang berarti bahwa industri meubel di Kecamatan Suruh Kabupaten Semarang layak untuk dilakukan. Berdasarkan analisis SWOT diketahui bahwa industri meubel di Kecamatan Suruh Kabupaten Semarang mempunyai keunggulan dalam produktivitas dan sumber daya, dan memiliki kelemahan dalam hal kurangnya peralatan, modal dan teknologi serta kurangnya promosi produk sehingga pemasarannya kurang maksimal. Industri meubel di Kecamatan Suruh Kabupaten Semarang memiliki peluang pasar yang cukup tinggi dan perhatian yang baik dari pemerintah dan memiliki ancaman dalam hal persaingan dengan industri meubel wilayah lain.

Analisa usaha Perikanan Budidaya yang dilakukan oleh Adi (2011) bertujuan untuk mengetahui gambaran secara jelas modal atau investasi yang diperlukan untuk operasional suatu usaha kegiatan produksi tambak per musim tanam atau dalam satu tahun. Secara garis besar petani atau pelaku usaha perikanan dapat mengetahui penerimaan dan keuntungan yang diperoleh serta beberapa lama kemungkinan modal investasi tersebut dapat dikembalikan. Penelitian ini dilakukan di Balai Besar Pengembangan Budidaya Air Payau Jepara, dengan jenis ikan bandeng, kerapu tikus, udang windu, udang vaname, dan bandeng. Hasil penelitian menunjukkan bahwa pembudidayaan di air payau dengan jenis ikan bandeng, kerapu tikus, udang windu, udang vaname, dan bandeng layak untuk dijalankan karena rata-rata B/C Ratio di atas satu, sedangkan kepercayaan dalam usaha ini rata-rata $500 \%$ sehingga usaha ini sangat menguntungkan. Sedangkan untuk pengembalian kredit usaha ratarata berkisar antara 6 bulan hingga 10 bulan.

Penelitian tentang Analisis kelayakan pengembangan usaha PT. Aneka Andalan Karya oleh Afandi (2009) ini bertujuan untuk mengetahui kelayakan rencana pengembangan usaha general supplier alat-alat keselamatan kerja dan kemampuan investasinya dalam memberikan keuntungan terhadap jumlah modal yang ditanam. Dari keseluruhan aspek yang diteliti, yaitu aspek pasar dan pemasaran, aspek teknis produksi dan teknologis, aspek manajemen dan sumber daya manusia, aspek hukum dan legalitas, serta aspek keuangan dan ekonomi menunjukkan bahwa kondisi PT. Aneka Andalan Karya pada saat ini layak untuk mengembangkan usahanya. Hasil perhitungan kelayakan analisis investasi menggunakan metode Payback Period (PP) menunjukkan bahwa waktu yang diperlukan untuk menutup investasi sebesar Rp. 311.000 .000 adalah 2 tahun 16 hari. Metode Average Range of Return (ARR) menunjukkan bahwa tingkat keuntungan rata-rata yang diperoleh sebesar $215,91 \%$. Metode Net Present Value (NPV) didapat nilai yang positif sebesar Rp. 225.586.113. Dari metode Internal Rate of Return (IRR) diperoleh tingkat bunga $37,77 \%$. Hasil ini menunjukkan bahwa tingkat pengembalian yang diperoleh lebih besar dari tingkat suku bunga yang ditentukan yaitu $14 \%$. Sedangkan metode Profitabilitas Indeks (PI) menunjukkan hasil yang diperoleh lebih besar dari 1 yaitu sebesar 1,72. Dari perhitungan lima metode tersebut dapat ditunjukkan juga bahwa rencana pengembangan usaha PT. Aneka Andalan Karya dapat diterima dan layak dilaksanakan.

\section{METODE PENELITIAN}

\subsection{Objek Penelitian}

Objek penelitian ini adalah warung lalapan “ PANGESTU" yang terletak di Kabupaten Jember dengan cabang di seluruh kecamatan kota Jember yang meliputi kecamatan Patrang, kecamatan Sumbersari dan kecamatan Kaliwates.

\subsection{Jenis dan Teknik Pengumpulan Data}

Penelitian ini merupakan penelitian studi kelayakan (Feasibility Study) yang bersifat evaluatif, yang ditujukan pada layak tidaknya suatu tindakan atau usaha yang dilakukan. Pada umumnya dilakukan di bidang ekonomi dan atau pembangunan disuatu wilayah/daerah tertentu. Studi Kelayakan merupakan penelitian terapan (Applied Research).

Sumber data dalam penelitian ini diperoleh dari wawancara dengan nara sumber. Dalam hal ini adalah pemilik waralaba warung "Pangestu" di kabupaten Jember. Adapun jenis data dalam penelitian ini ialah data kuantitatif berupa data biaya tetap, biaya variabel dan data pendapatan, sedangkan data kualitatif berupa keterangan, informasi, penjelasan, pendapat dan tanggapan dari pemilik. Sedangkan jenis data menurut sumbernya adalah data primer yang diperoleh secara langsung dari pemilik dan data sekunder yang diperoleh 
melalui studi pustaka mengenai studi kelayakan bisnis.

\subsection{Metode Pengumpulan Data}

Keberhasilan dalam pengumpulan data merupakan syarat bagi keberhasilan suatu penelitian. Sedangkan keberhasilan dalam pengumpulan data tergantung pada metode yang digunakan. Berkaitan dengan hal tersebut maka pengumpulan data diperlukan guna mendapatkan data-data yang obyektif dan lengkap sesuai dengan permasalahan yang diambil.

Metode pengumpulan data merupakan suatu cara untuk memperoleh kenyataan yang mengungkapkan data-data yang diperlukan dalam suatu penelitian. Dalam pengumpulan data yang diperlukan dalam penelitian ini digunakan metode wawancara langsung kepada nara sumber.

\subsection{Metode Analisis}

\subsubsection{Metode PP (Payback Period)}

Metode Payback Period (PP) merupakan teknik penilaian terhadap jangka waktu (periode) pengembalian investasi suatu proyek atau usaha. Jumlah Investasi x 12 bulan $P P=$

\section{Aliran Kas Bersih}

Kriteria penilaian pada payback period adalah :

o Jika Payback periodnya < waktu maksimum, maka usulan proyek tersebut dapat diterima.

o Jika Payback periodnya > waktu maksimum, maka usulan proyek tersebut ditolak.

\subsubsection{Metode B/C Ratio}

Metode $\mathrm{B} / \mathrm{C}$ ratio merupakan perbandingan antara total pendapatan selama masa tertentu dengan capital out lay.

$\mathrm{B} / \mathrm{C}$ Ratio $=\frac{\mathrm{TR}}{\mathrm{TC}}$

Kriteria penilaian B/C Ratio adalah :

o Jika $\mathrm{B} / \mathrm{C}>0$, maka usaha ini layak diusahakan.

o Jika $\mathrm{B} / \mathrm{C}<0$, maka usaha ini tidak layak diusahakan.

\subsubsection{Metode NPV (Net Present Value)}

Metode NPV (Net Present Value) merupakan metode analisis keuangan yang memperhatikan adanya perubahan nilai uang karena faktor waktu; proyeksi arus kas dapat dinilai sekarang (periode awal investasi) melalui pemotongan nilai dengan faktor pengurang yang dikaitkan dengan biaya modal (persentase bunga). NPV = Total PV Aliran Kas Bersih - Total PV Investasi

Kriteria penilaian NPV adalah : o Jika NPV > 0, maka investasi diterima.

o Jika NPV $<0$, maka investasi ditolak.

\subsubsection{Metode IRR (Internal Rate of Return)}

Metode IRR (Internal Rate of Return) adalah tingkat bunga yang akan diterima ( $P V$ Future Procceds) sama dengan jumlah nilai sekarang dari pengeluaran modal ( $P V$ Capital Outlays).

$$
\mathrm{IRR}=\mathrm{P} 1-\mathrm{C} 1 \mathrm{x} \quad \frac{\mathrm{P} 2-\mathrm{P} 1}{\mathrm{C} 2-\mathrm{C} 1}
$$

Keterangan :

$\mathrm{P} 1$ = Tingkat bunga 1

P2 = Tingkat bunga 2

$\mathrm{C} 1=\mathrm{NPV} 1$

$\mathrm{C} 2=\mathrm{NPV} 2$

Kriteria penilaian IRR adalah :

o Jika IRR > dari suku bunga yang telah ditetapkan, maka investasi diterima.

o Jika IRR < dari suku bunga yang telah ditetapkan, maka investasi ditolak.

\section{HASIL DAN PEMBAHASAN}

\subsection{HASIL}

\subsubsection{Gambaran Umum Perusahaan}

Warung Spesial Lalapan "PANGESTU" mulai berdiri awal tahun 2001. Nama PANGESTU diambil dari nama Sugeng Pangestu Pemilik dari warung makan PANGESTU, yang artinya adalah Do'a Restu atau Do'a Keselamatan (Bahasa Jawa). Pada awalnya PANGESTU adalah warung kaki lima yang berada di J1. Letjend panjaitan Depan Gedung Kejaksaan Lama (Sebelah barat RRI Jember ). Saat ini warung PANGESTU telah memiliki 11 cabang yang ada di wilayah Jember. Adapun cabang-cabang PANGESTU adalah :

1. PANGESTU 1 : Jl. Letjend Panjaitan Sumbersari (Sebelah Barat RRI Jember)

2. PANGESTU 2 : Jl. Letjend Suprapto Kebonsari (Depan Yon Armed 8 Jember)

3. PANGESTU 3 : Jl. Gajah Mada No. 297 Kaliwates (Depan Sentral YAMAHA Jember)

4. PANGESTU 4 : Jl. Slamet Riyadi Patrang (Sebelah Utara Selatan TMP Jember)

5. PANGESTU 5 : Jl. PB. Sudirman Pagah (Sebelah Utara Gedung Bayangkara Jember)

6. PANGESTU 6 : Jl. Brawijaya Jubung (Depan SMK Pertanian Jember)

7. PANGESTU 7 : Jl. Letjend Panjaitan No: 99 Sumbersari (Sebelah Timur RRI Jember)

8. PANGESTU 8 : Jl. Sumatra Kampus (Depan Pengadilan Agama Jember)

9. PANGESTU 9 : Jl. Teuku Umar Tegal Besar (Timur lampu merah Perum Tegal Besar Permai) 
10. PANGESTU $10: \mathrm{Jl}$. Mastrip Kampus (Depan Fakultas Kedokteran UNEJ Jember) sekarang sudah tutup.

11. PANGESTU 11 : Jl. Madura No. 76 Sumbersari (Timur RRI)

Dalam mengawali usaha khususnya usaha makanan / minuman ada banyak pertimbangan. Perasaan khawatir, takut, malu bercampur jadi satu. Rasa khawatir atau takut tidak laku, takut tidak boleh berjualan di jalan dan malu jika usahanya tidak berkelanjutan. Tetapi dengan niat dan tekad yang bulat serta melihat peluang yang ada bapak Sugeng memberanikan diri untuk memulai usaha tersebut. Pada saat itu Jember belum ada warung atau rumah makan yang mencantumkan daftar menunya adalah LALAPAN. Yang umum dicantumkan adalah Ayam Gorengnya. Bahkan pemilik warung PANGESTU berani mengklaim bahwa warung yang ada Pecek Terong dan Pecek Tempenya tertulis di spanduk atau daftar menu, yang pertama kali di jember adalah warung special lalapan PANGESTU.

Pada umumnya pedagang kaki lima menjual bakso, soto, gado - gado, pecel, dan rawon. Berbeda dengan warung PANGESTU yang menjual lalapan, meskipun menunya lalapan warung PANGESTU buka jam 10.00 WIB s/d 16.00 WIB (4 sore) seperti warung kaki lima pada umumnya. Semua produk yang dijual selalu habis sebelum jam 4 sore. Untuk menambah pendapatan dan tuntutan dari pelanggan, warung PANGESTU terus menambah jumlah dan jenis produk yang di jual, dan warung tutup hingga malam. Hingga saat ini terkenal bahwa warung PANGESTU buka 24 jam dan menerima pesan antar.

Melihat volume pengunjung / pelanggan yang stabil dan cenderung meningkat, pemilik warung PANGESTU mencoba untuk membuka cabang dan hingga sekarang mencapai 11 cabang PANGESTU. Untuk menjaga citra rasa warung PANGESTU menerapkan sistem terpusat artinya semua produk yang dijual, dikirim dari satu warung yaitu PANGESTU 7 (Jl. Letjend Panjaitan sebelah Timur RRI Jember). Sedangkan untuk pembuatan bumbu diracik sendiri dengan citra rasa khas "PANGESTU". Sedangkan untuk menjaga mutu dan pelayanan diadakanlah meeting di setiap cabang dan meeting bulanan untuk seluruh karyawan PANGESTU.

Dalam menentukan pembukaan cabang baru, ada beberapa pertimbangan antara lain Lokasi, Harga sewa tempat, dan karyawan yang akan melayani pelanggan. Targetnya adalah jalur masuk kota jember harus ada PANGESTU. Selain untuk menambah pendapatan, secara tidak langsung pembukaan cabang merupakan sebagian dari promosi.
Harga jual produk PANGESTU memiliki standar yang umum agar bisa dinikmati oleh semua kalangan. Ciri khas dari warung PANGESTU adalah sambalnya, karena lalapan identik dengan sambal. Sehingga setiap karyawan yang tugasnya membuat sambal harus di training dulu. Kami juga berusaha menarik minat pelanggan dengan mendesain warung secara sederhana dan dominan warna hijau, layanan pesan antar secara gratis dan dibuka 24 jam Non Stop. Selain itu, kami menawarkan program KUPON MAKAN GRATIS dan PAKET HEMAT.

Karyawan PANGESTU sekarang berjumlah kurang lebih 80 orang dan sebagian besar dari karyawannya adalah keluarga. Hal ini bertujun untuk membantu perekonomian keluarga. Mereka bertanggungjawab dalam pembuatan atau peracik bumbu. Sistem pembinaan karyawan dengan mengedepankan rasa kekeluargaan sehingga karyawan memiliki loyalitas yang tinggi. Hal ini merupakan salah satu faktor pendorong PANGESTU bisa mengembangkan usahanya dengan banyak membuka cabang. Karyawan yang diberi tanggung jawab di cabang PANGESTU yang baru adalah karyawan yang memiliki loyalitas yang tinggi. Agar terlihar rapi dan bersih seluruh karyawan berseragam.

Warung PANGESTU memiliki pembukuan walaupun secara sederhana. Pembukuan yang dibuat meliputi pengeluaran, pendapatan dan keuntungan usaha, baik percabang maupun seluruh PANGESTU. Investasi awal yang ditanamkan oleh pemilik terdapat dalam tabel 5.1. 

Dessy Putri A, Studi Kelayakan Usaha Waralaba Warung PANGESTU” Di Kabupaten Jember

Tabel 5.1 Investasi Dalam Aktiva Tetap Warung Lalapan "Pangestu" untuk satu cabang

\begin{tabular}{|c|c|c|c|c|c|c|}
\hline No. & Nama Investasi & Jumlah & Umur & Harga/Unit (Rp) & Nilai (Rp) & Susut/th (Rp) \\
\hline 1 & Etalase & 1 & 5 & 2.500 .000 & 2.500 .000 & 500.000 \\
\hline 2 & Meja makan & 6 & 5 & 350.000 & 2.100 .000 & 420.000 \\
\hline 3 & Kompor gas & 2 & 5 & 250.000 & 500.000 & 100.000 \\
\hline 4 & Tabung gas $(3 \mathrm{~kg})$ & 2 & 5 & 100.000 & 200.000 & 40.000 \\
\hline 5 & Rice cooker & 2 & 5 & 550.000 & 1.100 .000 & 220.000 \\
\hline 6 & Kalkulator & 1 & 5 & 175.000 & 175.000 & 35.000 \\
\hline 7 & Sendok & 100 & - & 2.000 & 200.000 & - \\
\hline 8 & Garpu & 100 & - & 2.000 & 200.000 & - \\
\hline 9 & Gelas & 100 & - & 3.000 & 300.000 & - \\
\hline 10 & Piring Melamin & 100 & - & 2.000 & 200.000 & - \\
\hline 11 & Mangkok kecil & 100 & - & 2.000 & 200.000 & - \\
\hline 12 & Pisau daging & 2 & - & 75.000 & 150.000 & - \\
\hline 13 & Pisau & 4 & - & 20.000 & 80.000 & - \\
\hline 14 & Cobek besar & 2 & 5 & 50.000 & 100.000 & 20.000 \\
\hline 15 & Panci besar dan kecil & 10 & 5 & 350.000 & 1.750 .000 & 31.000 \\
\hline 16 & Piring oval besar & 10 & - & 25.000 & 250.000 & - \\
\hline 17 & Baskom/ember besar dan kecil & 3 & - & 30.000 & 90.000 & - \\
\hline & Total biaya (Rp) & & & & 10.095 .000 & 1.366 .000 \\
\hline
\end{tabular}

Dikarenakan proyek ini adalah usaha rumah makan yang pastinya harga di pasar tak menentu sehingga penulis membuat asumsi pada biaya variabel tahun 1 sampai dengan tahun ke 5 mengalami kenaikan sebesar $10 \%$. Perincian proyeksi biaya variabel dan biaya tetap dapat dilihat pada tabel 5.2

Tabel 5.2 Proyeksi Biaya Variabel dan Biaya Tetap Warung Lalapan "Pangestu" (Satu Cabang) (dalam Rupiah) Tabel 5.3 Proyeksi Aliran Kas (Cash Flow) (dalam Rupiah)

\begin{tabular}{|c|c|c|c|c|c|}
\hline \multirow[b]{2}{*}{ KETERANGAN } & \multicolumn{5}{|c|}{$\begin{array}{l}\text { Tahun Ke - } \\
\end{array}$} \\
\hline & 1 & 2 & 3 & 4 & 5 \\
\hline \multicolumn{6}{|c|}{ ARUS KAS OPERASI: } \\
\hline Penjualan & 1.182 .649 .232 & 1.247 .159 .461 & 1.371 .875 .645 & 1.473 .226 .816 & 1.605 .617 .858 \\
\hline Biaya Variabel & 929.710 .925 & 1.022 .682 .018 & 1.124 .950 .219 & 1.237 .445 .241 & 1.361 .189 .765 \\
\hline \multirow[t]{2}{*}{ Biaya Tetap } & 46.915 .000 & 51.606 .500 & 56.767 .150 & 62.443 .865 & 68.688 .252 \\
\hline & 882.795 .925 & 971.075 .518 & 1.068 .183 .069 & 1.175 .001 .376 & 1.292 .501 .513 \\
\hline EBT & 299.853 .307 & 276.083 .943 & 303.692 .576 & 298.225 .440 & 313.116 .345 \\
\hline Tax & 29.985 .331 & 27.608 .394 & 30.369 .258 & 29.822 .544 & 31.311 .635 \\
\hline EAT & 329.838 .638 & 303.692 .337 & 334.061 .834 & 328.047 .984 & 344.427 .980 \\
\hline \multicolumn{6}{|c|}{ ARUS KAS INVESTASI : } \\
\hline Depresiasi & 1.366 .000 & 1.366 .000 & 1.366 .000 & 1.366 .000 & 1.366 .000 \\
\hline Pembelian Aktiva Tetap & \begin{tabular}{l|l}
- & \\
\end{tabular} & - & - & - & - \\
\hline Penjualan Aktiva Tetap & 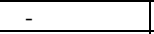 & \begin{tabular}{l|l}
- & \\
\end{tabular} & \begin{tabular}{l|l}
- & \\
\end{tabular} & \begin{tabular}{l|l}
- & \\
\end{tabular} & - \\
\hline Arus Kas Bersih & 331.204 .638 & 305.058 .337 & 335.427 .834 & 329.413 .984 & 345.793 .980 \\
\hline
\end{tabular}




\subsubsection{Analisis menggunakan Aspek Keuangan \\ 1. Perhitungan Payback Period (PP)}

Berdasarkan pengembalian investasi suatu proyek atau usaha dapat diketahui bahwa Payback Period (PP) warung makan Lalapan "Pangestu" adalah :

Investasi Awal

Rp. 897.936 .750

Arus Kas Bersih Tahun 1 Rp. (331.204.638) Rp. 566.732.112

Arus Kas Bersih Tahun 2 Rp. (305.058.337) Rp. 261.673 .775

Arus Kas Bersih Tahun 3 Rp. (335.427.834) Rp. -73.754 .059$

Payback Period $(\mathrm{PP})=2$ tahun 2 bulan 20 hari

\section{Perhitungan $B / C$ Ratio}

$\mathrm{B} / \mathrm{C}$ ratio merupakan perbandingan antara total pendapatan selama masa tertentu dengan capital out lay. Dihitung dengan rumus :

$$
\mathrm{B} / \mathrm{C} \text { Ratio }=\frac{\mathrm{TR}}{\mathrm{TC}}
$$

\section{Perhitungan NPV (Net Present Value)}

NPV (Net Present Value) memperhatikan adanya perubahan nilai uang karena faktor waktu; proyeksi arus kas dapat dinilai sekarang (periode awal investasi) melalui pemotongan nilai dengan faktor pengurang yang dikaitkan dengan biaya modal (persentase bunga).

Tabel 5.4 Perhitungan NPV warung makan

\begin{tabular}{|c|c|c|c|}
\hline Thn & Proceed & $\begin{array}{c}\text { DF } \\
15 \%\end{array}$ & PV \\
\hline 1 & 331.204 .638 & 0,870 & 288.148 .035 \\
\hline 2 & 305.058 .337 & 0,756 & $230.624 .102,7$ \\
\hline 3 & 335.427 .834 & 0,658 & $220.711 .514,7$ \\
\hline 4 & 329.413 .984 & 0,572 & $188.424 .798,8$ \\
\hline 5 & 345.793 .980 & 0,497 & 171.859 .608 \\
\hline \multicolumn{3}{|c|}{ NPV } & 1.099 .768 .059 \\
\hline
\end{tabular}
Lalapan "Pangestu"

$\mathrm{NPV}=1.099 .768 .059>897.936 .750$ maka Layak Diusahakan

\section{Perhitungan IRR (Internal Rate of Return)} IRR (Internal Rate of Return) warung Lalapan "Pangestu" adalah :

\begin{tabular}{|l|l|l|l|}
\hline Thn & Proceed & DF & PV \\
\hline
\end{tabular}

Sehingga B/C Ratio warung makan lalapan "Pangestu adalah :

1.182 .649 .232

B/C Ratio tahun $1=$

882.795 .925

Layak diusahakan

$$
=1,34>0 \text { artinya }
$$

B/C Ratio tahun $2=$

$$
\text { 1.247.159.461 }
$$

971.075 .518

$$
=1,28>0 \text { artinya }
$$

Layak diusahakan

$$
\text { 1.371.875.645 }
$$

B/C Ratio tahun $3=$

1.068.183.069

Layak diusahakan

$$
=1,28>0 \text { artinya }
$$

B/C Ratio tahun $4=$

$$
\text { 1.473.226.816 }
$$

1.175 .001 .376

$=1,25,0$ artinya

Layak diusahakan

$$
1.605 .617 .858
$$

$\mathrm{B} / \mathrm{C}$ Ratio tahun $5=$

1.292 .501 .513

$=1,24$, 0 artinya

Layak diusahakan

\begin{tabular}{|l|c|c|c|}
\hline & & $\mathbf{4 0 \%}$ & \\
\hline 1 & 331.204 .638 & 0,714 & 236.480 .111 \\
\hline 2 & 305.058 .337 & 0,510 & 155.579 .752 \\
\hline 3 & 335.427 .834 & 0,364 & 122.095 .731 \\
\hline 4 & 329.413 .984 & 0,260 & 85.647 .636 \\
\hline 5 & 345.793 .980 & 0,186 & 64.317 .680 \\
\hline \multicolumn{3}{|c|}{ NPV } & 664.120 .910 \\
\hline
\end{tabular}

$$
\begin{aligned}
\text { IRR } & =\frac{0,15+1.099 .768 .059 \times(0,4-0,15)}{201.831 .309-233.815 .840} \\
& =8,595>0,15 \text { maka Layak }
\end{aligned}
$$

\subsection{PEMBAHASAN}

Dari analisis kelayakan usaha diperoleh hasil NPV dan IRR yang menunjukkan bahwa usaha ini layak untuk diusahakan, sedangkan perhitungan Payback Period (PP) warung makan Lalapan "Pangestu" memiliki tingkat pengembalian modal yang cukup cepat yaitu 2 tahun 2 bulan dan 20 hari. Hal ini akan menarik minat investor yang ingin berwirausaha. Jika cabang yang ada di warung makan Lalapan "Pangestu" dibuat waralaba dengan tingkat pengembalian seperti 
diatas tidak menutup kemungkinan para pembeli waralaba akan banyak. Sehingga ini akan menguntungkan pemilik karena dengan adanya waralaba pemilik tidak lagi bingung mencari tempat untuk memperlebar usahanya dan tidak perlu menggaji karyawan karena semua merupakan tanggungan dari pembeli waralaba.

Beberapa hal yang perlu diperhatikan dalam menjual waralaba hampir sama dengan jika kita membuka cabang yaitu letak warung yang akan kita buka. Hal ini merupakan faktor penentu keberhasilan suatu usaha. Jarak antar warung juga harus diperhatikan agar konsumen warung makanan Lalapan "Pangestu" bisa dibagi rata, dan antar warung tidak berebut konsumen. Hal juga ini akan memudahkan konsumen dalam menjangkau warung makanan Lalapan "Pangestu". Untuk tetap menjaga kualitas dari makanan yang dijual, pemilik tetap harus memperhatikan cita rasa dari sambal yang merupakan ciri khas dari warung makanan Lalapan "Pangestu" dengan cara melakukan training untuk karyawan baru. Selain itu kebersihan warung juga harus menjadi prioritas utama bagi pembeli waralaba yang harus ditekankan oleh pemilik. Sehingga warung makanan Lalapan "Pangestu" tetap disukai oleh konsumennya.

Warung makanan saat ini merupakan usaha yang mudah dilakukan dan memiliki resiko yang sangat kecil dibandingkan dengan usaha yang lain. Jumlah masyarakat yang terus bertambah merupakan keuntungan bagi usaha warung makanan. Selain itu karena warung makanan Lalapan "Pangestu" sudah memiliki nama bagi pewaralaba merupakan suatu keuntungan yang luar biasa.

\section{KESIMPULAN DAN SARAN}

\subsection{KESIMPULAN}

Dari hasil analisis kelayakan usaha warung makan Lalapan "Pangestu" dengan menggunakan metode Payback Period, metode Benefit Cost Ratio (BCR), metode Net Present Value (NPV) dan metode Internal Rate of Return (IRR) usaha warung makan Lalapan "Pangestu" dikatakan layak untuk diusahakan. Hasil perhitungan dengan menggunakan metode Payback Period diperoleh hasil, yaitu 2 tahun 2 bulan 20 hari lebih cepat dari umur ekonomis usaha selama 5 tahun. BCR memiliki nilai lebih dari 1 yang menunjukkan bahwa usaha ini layak untuk diusahakan. $N P V$ bernilai positif, yaitu Rp. 1.099.768.059. IRR bernilai $85,95 \%$ lebih besar dari tingkat bunga yang telah ditetapkan yaitu $15 \%$.
Sehingga jika usaha ini diwaralabakan pasti banyak yang akan membeli usaha ini. Ada beberapa hal yang tetap harus diperhatikan pemilik agar usaha ini tetap eksis yaitu letak warung satu dengan lainnya, kebersihan dan keterampilan dalam membuat sambal sebagai makanan khas warung makan Lalapan "Pangestu".

\subsection{SARAN}

Ada beberapa saran yang bisa penulis berikan yaitu :

1. Untuk Peneliti Selanjutnya, penelitian kelayakan usaha di bidang yang lain sangat dibutuhkan agar tercipta lapangan usaha baru dan membuka jiwa wirausaha bagi masyarakat.

2. Untuk Pemilik, selalu menambah outlet-outlet baru agar tercipta lapangan kerja baru dan menambah penghasilan bagi pemilik dengan tetap menjaga kebersihan dan kekhasan dari warung tersebut.

3. Untuk pemerintah, memberikan fasilitasfasilitas dan memberi kemudahan UKM UKM untuk terus berkembang agar tidak kalah dengan usah-usaha modern yang saat ini marak berkembang.

\section{DAFTAR PUSTAKA}

Adi, Sapto, 2011, Analisis Usaha Perikanan Budidaya, Badan Pengembangan SDM Kelautan dan Perikanan Kementerian Kelautan dan Perikanan : Jakarta

Budi Frensidy, 2008. Financial Mathematics, Salemba Empat : Jakarta

Ekotama, Suryono, 2008, Cara Gampang Bikin Bisnis Franchise, Media Pressindo : Jakarta

Freddy Rangkuti, 2006. Business Plan, Teknik Membuat Perencanaan Bisnis dan Analisis Kasus, PT Gramedia Pustaka Utama : Jakarta

Horne, Van, James C, John M. Wachowicz, Jr, 1997. Prinsip-Prinsip Manajemen Keuangan Edisi Sembilan, Salemba Empat : Jakarta

Husnan, Suad, 1996, Manajemen Keuangan Teori dan Penerapan, BPFE : Yogyakarta

Husnan, Suad dan Suwarsono, Studi Kelayakan Proyek : Konsep, Teknik dan Penyusunan Laporan, UPP AMP YKPN, Yogyakarta, 2000 
Jurnal Ilmiah INOVASI, Vol.13 No.2, Hal. 154-164, ISSN 1411-5549

Ibrahim, Yacob, Studi Kelayakan Bisnis Edisi Revisi, Rineka Cipta, 2003

Keown J Arthur, et. al, 2001. Dasar-dasar Manajemen Keuangan, Edisi 7, Salemba Empat : Jakarta
Munawir, 1997, Analisa Keuangan, Liberty : Yogyakarta

Raharjo, Budi, 2009, Analisis Kelayakan Usaha dan Strategi Pengembangan Industri Kecil Meubel di Kecamatan Suruh Kabupaten Semarang, Skripsi, Universitas Negeri Semarang : Semarang 